\title{
REPRODUCTION PERFORMANCE OF BEEF CATTLE BEFORE AND AFTER IMPLEMENTING A SUSTAINABLE GRAZING SYSTEM IN A SEMI-ARID GRASSLAND OF SOUTHERN AFRICA
}

\author{
Van der Westhuizen, H. C. ${ }^{1}$, Mohlapo, T. D. ${ }^{2}$, De Klerk, J. D. ${ }^{3}$, Majola, S. E. ${ }^{4}$, Snyman, H. A. ${ }^{5}$
} and Neser, F. W. C. ${ }^{6}$

Correspondence author: H. C. van der Westhuizen. Email: mias@fs.agric.za

\begin{abstract}
The semi-arid grasslands of South Africa are a major resource for beeffarming. However, the reproduction performance of beef cattle is not optimal, and it is stressed differently by the different agriculture sectors due to various management systems. The aim of this study was to investigate the impact of sustainable rangeland management on the reproduction of beef cattle and rangeland health. Data on calving rates, weaning weight (205 days), and rangeland condition over a period of five years was sampled, beginning with no rangeland management in year one, comparing the results with the next four years after implementing sustainable rangeland management, utilising the same herd of cattle. Results showed a significant increase in calving rates from the first year of rangeland management $(+27 \%)$, with a $50 \%$ increase in year four. Weaning weight also increased significantly $(P<0.05)$ within the first year $(+60$ $\mathrm{kg}$ ), with $72.8 \mathrm{~kg}$ in year four. Rangeland conditions also started to improve in 31 of the 45 camps. The financial implication with respect to weaner calf income was also calculated with striking differences within the first year where it was \pm two to three times higher and four times higher in year four comparing with the income with no rangeland management. Agricultural extension will enhance the objectives of securing sustainable agricultural development as indicated in this study for livestock production through the implementation of efficient rangeland management.
\end{abstract}

Keywords: Beef production, Calving rate, Economic implications, Rangeland management

\section{INTRODUCTION}

South African beef producers are confronted by many socio-economic and management challenges that have a negative effect on beef production and thus profitability. Production information from the different agricultural sectors in South Africa has been well documented by Scholtz and Bester (2010). They reported an average estimated calving rate of $62 \%$ for

\footnotetext{
${ }^{1}$ Professional Scientist: Range and Forage Science, Free State Department of Agriculture and Rural Development, Glen, South Africa, Email: mias@fs.agric.za

${ }^{2}$ Professional Scientists: Animal Science, Free State Department of Agriculture and Rural Development, Glen, South Africa, Email: daniel@fs.agric.za

${ }^{3}$ Scientific Technician: Animal Science, Free State Department of Agriculture and Rural Development, Glen, South Africa, Email: diedericht@fs.agric.za

${ }^{4}$ Professional Scientists: Animal Science, Free State Department of Agriculture and Rural Development, Glen, South Africa, Email: sechaba@fs.agric.za

${ }^{5}$ Professor, Department of Animal, Wildlife and Grassland Sciences, University of the Free State, Bloemfontein, South Africa, Email: hensny1@gmail.com

${ }^{6}$ Professor and Head, Department of Animal, Wildlife and Grassland Sciences, University of the Free State, Bloemfontein, South Africa, Email: neserfw@ufs.ac.za, ORCID nr.: 0000-0002-2202-6418
} 
commercial farmers, $48 \%$ for the emerging sector, and $35 \%$ for the communal sector. Many studies have focused on issues such as breeding, selection, supplementary feeding, and livestock management to increase livestock production (Grobler et al, 2014). Efficient rangeland management, however, is seldom mentioned.

Furthermore, $70 \%$ of agricultural land in South Africa can only be utilised by livestock and game (Meissner, Scholtz \& Palmer, 2013). Natural rangeland forms the basis of the extensive livestock industries, especially in semi-arid environments where the rainfall is low and unpredictable. Due to increasing climate variability and the threads of global warming, midsummer droughts became more the norm than the exception. Efficient rangeland management should ensure that the quantity of forage during these times is sufficient for sustainable livestock production. As these mid-summer droughts coincide with the mating season, it can contribute to the low reproduction rate in beef herds. South Africa is still a net importer of beef, mainly due to the low levels of production. South Africa will be able to move to self-sufficiency if the average calving rate and the off-take are increased, especially in the communal and emerging sectors (Grobler et al, 2014).

Grazing management in South Africa was summarised by Van Der Westhuizen, Snyman and Fouché (2018) as follows: A communal production sector characterised by lack of land ownership and maintenance of farm planning (fences, windmills and water supply) is not up to standard. Continuous grazing is therefore commonly applied. As for the emerging sector, grazing management varies from continuous grazing to two, three and four camp systems. The fact that many developing small holding farmers come from a communal livestock farming background, whereby rangeland management and beef production practices seldom exist, poor livestock performance (calving rate of $48 \%$ ) and natural resource degradation are most evident. In the commercial sector, the grazing area is subdivided into more camps than there are groups of animals. At any given time, the animals only stay on part of the farming unit and this allotted period is determined by the number of camps per herd. The other camps get a chance to rest for a certain period of time.

The aim of this study is therefore to determine the influence of rangeland management on beef production and rangeland condition, and subsequently, a tool to empower extension with research information that addresses sustainability through rangeland management. The reproduction performance and rangeland health are however the most important factors influencing the sustainability and profitability of extensive livestock production. As sustainable rangeland management is essential in extensive livestock systems, it is important that the results of this study are conveyed to farmers. The role of agricultural extension is essential in conveying and facilitation in the implementation of this research outcome.

\section{MATERIALS AND METHODS}

\subsection{Study area}

The research was conducted at the Glen experimental farm of the Free State Department of Agriculture and Rural Development (26 $20^{\prime} \mathrm{E}$; $\left.28^{\circ} 57^{\prime} \mathrm{S}\right)$ in the magisterial district of the city of Bloemfontein in the central Free State. The altitude varies from $1320 \mathrm{~m}$ to $1420 \mathrm{~m}$ above sea level. The dominant soil form in the area is Milkwood, Arcadia and Valsrivier, with more than $35 \%$ clay (MacVicar et al, 1977). The average annual rainfall, based on records of 95 years, is $556 \mathrm{~mm}$, of which more than $70 \%$ falls during the period November to March (ISCW-databank, 
2018). Summer temperatures are moderate to warm with very cold winters. Frost occurs from the middle of April to the middle of October. The average length of the frost period is 175 days, while the length of the growing season varies from 168 to 212 days.

\subsection{Vegetation type and degradation indicators}

Acocks (1988) classified the vegetation as the dry Cympopogon Themeda vegetation type, while the relative homogenous area is classified by Van Der Westhuizen (2003) as the Themeda vegetation of the central Free State. Vegetation can be described as sweet grassveld, where the plant cover is dominated with dense stands of Themeda triandra when it is in a well conserved condition. Degradation processes can clearly be characterised by changes in the relation between T. triandra, Eragrostis chloromelas, Aristida species and Cynodon hirsutus. With poor rangeland management, $T$. triandra decreases firstly at the expense of E. chloromelas, followed by Aristida species, and lastly by $C$. hirsutus (Van Der Westhuizen, Van Rensburg \& Snyman, 1999). Soil degradation due to unsustainable veld management practices is a serious environmental problem. According to Van Der Westhuizen (2003), the increase of phosphate (P) in the topsoil is the dominant soil indicator with respect to vegetation change for this vegetation type. Phosphate accumulation increases in degraded rangelands is due to supplementary feeding given to the livestock (Kotze et al, 2013; Van Der Westhuizen, 2003). The loss in the functioning of the ecosystem is about $25 \%$ in terms of grazing capacity if $\mathrm{P}$ levels increase to $2 \mathrm{mg} / \mathrm{kg}$, but it could reach up to $60 \%$ loss in grazing capacity if $\mathrm{P}$ levels increase to 29mg/kg (Van Der Westhuizen, 2003). Van Der Westhuizen and Snyman (2014) state that because $\mathrm{P}$ is static and does not leach from the soil, it is indicative that it has a major influence on the process of rangeland improvement and sustainability. They further stated that the injudicious application of licks as nutritional supplements had an accelerating long-term effect on the build-up of $\mathrm{P}$ in the soil. They then recommend that beef producers should focus on rangeland management and stocking rate rather than applying too many licks and nutritional supplements to their grazing herds, as these can have a negative influence on rangeland condition, grazing capacity and sustainable animal production in the long-term.

\subsection{Methods}

A sample of 195 Bonsmara females were used in this study. Data were collected over a period of five years. Calving rate and weaning weight at 205 days was monitored over the trail period, starting with no veld management inputs at the beginning of the trial. Animals were then divided into five herds and a multi camp grazing system was implemented. Females were proportionally divided into groups using age, metabolic body weight (Meissner et al, 1983), and previous calving records. The herds were extensively managed, and animals did not receive any production or protein supplements. Herd management practices were executed for extensive beef production according to the Glen beef management programme (Free State Department of Agriculture and Rural Development (FSDARD), 2004). The breeding season commenced on the first day of December each year and ended at the end of February (90 days), and the calves were weaned at an average age of seven months. Rainfall data were collected daily, and a mathematical rangeland production model (Fouché, 1992) was used to analyse the effect of rainfall on available fodder over the trial period. A stocking rate of 6ha/LSU, that concedes with the departmental grazing capacity of the area, was adhered to for four of the herds, while a variable stocking rate, as determined by the results of a seasonal rangeland analysis, was followed for the fifth herd. Rangeland analyses included rangeland condition assessments as well as the effect of rainfall variation on the grazing capacity. For the grazing 
system, 45 camps were randomly divided into five groups by using terrain types and rangeland condition (nine camps for every herd). Camps were grazed for a period of one to three months, depending on the camp size, with a resting period that varied from three to 13 months with an average resting period of eight months. Over the four years that the grazing system was implemented, every camp received a full growing season's rest.

\subsection{Data collection and analysis}

Descriptive statistics, namely mean scores and standard deviations, were calculated for every year, while an analysis of variance (ANOVA) was used to compare the mean values and the mean differences between the five years.

The species composition of the herbaceous layer was determined based on frequency of occurrence using a fixed line transect for every camp. The nearest plant was recorded for 200 point observations per camp. This sampling size has been shown to be adequate for detailed scientific studies (Hardy \& Walker, 1991). The trends in rangeland condition were determined for every camp using the indicator species technique, developed and tested against a degradation gradient technique specifically for this vegetation type (Van Der Westhuizen, 2003).

\section{RESULTS AND DISCUSSIONS}

\subsection{Reproduction performance}

Calving rate, as defined as all calves born as the percentage of total cows and heifers mated, and weaning weight (205 days) increased significantly ( $\mathrm{P}<0.05)$ after the implementation of a multi camp grazing system. The calving rate increased from $32 \%$ with no veld management inputs to $82 \%$ in year four after implementing a multi camp grazing system (Table 1). The calving rate of $32 \%$ in the 195 Bonsmara cows and heifers was comparable to the results obtained by Scholtz and Bester (2010) for the communal sector. As both rainfall and available fodder, especially during the breeding season, can contribute to the calving rate, the total spring and summer rainfall (September-February) is also presented in Table 1. From this data, it is clear that the rainfall conditions three months before the breeding season and during the breeding season did not play a role in the differences in calving rate prior to $(346 \mathrm{~mm})$ and after implementing the grazing system $(313-459 \mathrm{~mm})$. Weaning weight increased with 60kg within one year after implementing a multi camp grazing system. As these results could be influenced by climatic conditions, an indication of seasonal fodder production was simulated for every season using a mathematical rangeland production model (Fouché, 1992). Rangeland production was then classified into different groups as indicated in Table 1. Significant differences between year three and the other rangeland management years could be explained by a drought as well as very little rainfall from the beginning of January until the end of March. During this period, only $71 \mathrm{~mm}$ was received in comparison with the long term average of $248 \mathrm{~mm}$. According to Van Der Westhuizen (2006), the average contribution to rangeland production for these three months is about $68 \%$. It is also interesting to note that very high rainfall and rangeland production during the second year did not contribute to higher weaning weights, which could probably be linked to the fact that higher rainfall increases rangeland production, but it reduces veld quality. 
Table 1: Reproduction performance, pre-breeding and breeding season rainfall (SepFeb), as well as an indication of seasonal rangeland production over the trial period

\begin{tabular}{|l|l|l|l|l|}
\hline $\begin{array}{l}\text { Years after } \\
\text { implementation }\end{array}$ & $\begin{array}{l}\text { Sep-Feb } \\
\text { rainfall } \\
(\mathbf{m m})\end{array}$ & $\begin{array}{l}\text { Calving } \\
\text { \% } \pm \text { SD }\end{array}$ & $\begin{array}{l}\text { Weaning weight } \\
(\mathbf{k g}) \text { 205 days } \pm \\
\text { SD }\end{array}$ & $\begin{array}{l}\text { Simulated } \\
\text { seasonal } \\
\text { production }\end{array}$ \\
\hline $\begin{array}{l}\text { No } \\
\text { management inputs }\end{array}$ & 346 & $32^{\mathrm{a}} \pm 10$ & $155.8^{\mathrm{a}} \pm 11.1$ & Normal \\
\hline Year 1 & 342 & $59^{\mathrm{b}} \pm 19$ & $215.8^{\mathrm{c}} \pm 6.7$ & Below normal \\
\hline Year 2 & 313 & $60^{\mathrm{b}} \pm 12$ & $214.4^{\mathrm{c}} \pm 10.1$ & Very high \\
\hline Year 3 & 459 & $62^{\mathrm{b}} \pm 15$ & $190.0^{\mathrm{b}} \pm 9.6$ & Very low \\
\hline Year 4 & 313 & $82^{\mathrm{c}} \pm 7$ & $228.6^{\mathrm{d}} \pm 6.7$ & Normal \\
\hline
\end{tabular}

$\mathrm{a}, \mathrm{b}, \mathrm{c}, \mathrm{d}-$ Values (mean $\pm \mathrm{SD}$ ) within a column followed by different superscript letters are significantly different $(\mathrm{P}<0.05), \mathrm{SD}=\mathrm{Standard}$ deviation

This information indicates that the reproduction performance of producers, especially in the emerging and communal sector, could be increased drastically with the implementation of efficient grazing management. The increase in calving rates of the variable stocking rate group was most striking in comparison with the other herds. After four years, the calving rate of this group increased to $92 \%$. This is even more remarkable when it is considered that heifers in this group were subjected to early mating (14-16 months of age), while animals were only supplemented with salt. Reproduction performance in this herd is compared with the other herds in Table 2 for the third and fourth year. Due to variable seasonal rainfall conditions, the grazing capacity of the veld varied accordingly to the rainfall. This was especially true during the starting period of the mating season (December-January) when mid-season droughts can restrict consumption rate.

Table 2: Comparison of reproduction performance between fixed and variable stocking rate $(\%)$

\begin{tabular}{|c|c|c|c|c|}
\hline \multirow{2}{*}{$\begin{array}{l}\text { Years } \\
\text { implementation } \\
\text { rangeland management }\end{array}$} & \multicolumn{2}{|c|}{ Fixed stocking rate } & \multicolumn{2}{|c|}{ Variable stocking rate } \\
\hline & $\begin{array}{l}\text { Calving rate } \\
(\%)\end{array}$ & $\begin{array}{l}\text { Weaning } \\
\text { weight }(\mathrm{kg})\end{array}$ & $\begin{array}{l}\text { Calving } \\
\text { rate }(\%)\end{array}$ & $\begin{array}{l}\text { Weaning } \\
\text { weight (kg) }\end{array}$ \\
\hline Year 3 & 58 & 188 & 76 & 198 \\
\hline Year 4 & 80 & 228 & 92 & 233 \\
\hline
\end{tabular}

\subsection{Rangeland condition}

An improvement in rangeland condition was measured in 31 of the 45 camps utilised. Rangeland improvement is a slow process and the time for species turnover is unknown. This, together with the fact that the grazing history of camps before the trial started is unknown, could contribute to the 14 camps that did not improve. Rangeland improvement in the 31 camps varied from starting to improve (1-5\% improvement in 20 camps) to moderate improvement (6-10\% improvement in 9 camps). However, the largest increase in rangeland condition (> $11 \%$ ) occurred in two camps. As indicated in Table 3, one of these camps is used as an example to illustrate the improvement in the proportional species composition as surveyed at the start of the trial and four years later. The most abundant species were Digitaria argyrograpta, 
Tragus koelerioides, and Aristida canescens at the start of the trial. Digitaria argyrograpta was however replaced as dominant species by $T$. triandra, at the expense of mainly $T$. koelerioides.

The importance of $T$. triandra as a key species for this vegetation type is continually emphasised. This species is not only the ecologically most important species in the study area, but also a very good indicator of rangeland condition $\left(r^{2}=0.99\right)$ (Van Der Westhuizen, 2003; Van Der Westhuizen et al, 1999), as well as the most important species in the diet of both sheep (37\%) and cattle (48\%) for this semi-arid vegetation type (Van Der Westhuizen et al, 2001).

\subsection{Economic implications}

The improvements in the income over the trial period are presented in Table 4. For these calculations, the real weaner calf price of R30 per $\mathrm{kg}$ at the end of the trial was used. The difference in weaner calf income per cow increased approximately two and a half times within only one year and about four times after four years of implementation of a rangeland management programme. As indicated in Table 1 and Table 4, a drastic increase in calving rate, from $32 \%$ to $59 \%$ ( $27 \%$ increase), and weaning weight, from $155.8 \mathrm{~kg}$ to $215.8 \mathrm{~kg}$ (60kg increase), were experienced after the first year of implementation.

The variable stocking rate treatment outscores the fixed stocking rate with R959 per cow after four years of rangeland management (Table 4.) The practical implementation of the variable stocking rate should, however, be further investigated. Due to increasing climate variability and the threads of global warming, as well as the effect on the environment in terms of rangeland condition, variable stocking rates according to rangeland potential would play a major role in sustainable beef production in the future.

Table 3: An example of proportional species composition (\%) and rangeland condition $(\%)$ at the beginning, and again four seasons later at the end of the trail for one camp

\begin{tabular}{|l|l|l|l|}
\hline Species & I & Start (season 1) & End (season 4) \\
\hline Themeda triandra & 10 & 12.9 & 20.7 \\
\hline Eragrostis lehmanniana & 7 & 4.0 & 4.5 \\
\hline Eragrostis superba & 6 & 0.0 & 0.5 \\
Heteropogon contortus & & 7.0 & 2.0 \\
\hline Sub total & & 7.0 & 2.5 \\
\hline Digitaria argyrograpta & & 19.9 & 14.6 \\
Microchloa caffra & 5 & 1.0 & 0.0 \\
Tragus koelerioides & & 17.4 & 7.1 \\
\hline Sub total & & 38.3 & 21.7 \\
\hline Aristida canescens & & 14.4 & 17.2 \\
Aristida congesta & & 5.0 & 5.6 \\
Aristida diffusa & 4 & 2.5 & 0.0 \\
Cymbopogon pospischilii & & 10.0 & 17.2 \\
Eragrostis chloromelas & & 0.5 & 0.5 \\
\hline Sub total & & 32.4 & 40.5 \\
\hline Elionurus muticus & 3 & 0.0 & 0.5 \\
\hline Annual Herbs & & 0.5 & 7.6 \\
Eragrostis obtusa & 2 & 2.5 & 0.5 \\
Sporobolus fimbriatus & & 1.5 & 0.0 \\
\hline
\end{tabular}




\begin{tabular}{|l|l|l|l|}
\hline Sub total & & 4.5 & 8.1 \\
\hline Helichrysum dregeanum & 1 & 1.0 & 0.5 \\
Felicia muricata & & 0.0 & 0.5 \\
\hline Sub total & & 1.0 & 1.0 \\
\hline Total & & 100 & 100 \\
\hline Rangeland condition & & $\mathbf{2 7}$ & $\mathbf{3 8}$ \\
\hline
\end{tabular}

$\mathrm{I}=$ Ecological index values

Table 4: Comparison of weaner calf income per cow

\begin{tabular}{|l|l|l|l|l|}
\hline & $\begin{array}{l}\text { No rangeland } \\
\text { management }\end{array}$ & $\begin{array}{l}\text { First year after } \\
\text { implementation of } \\
\text { rangeland } \\
\text { management }\end{array}$ & $\begin{array}{l}\text { Rangeland } \\
\text { management: } \\
\text { Fixed stocking } \\
\text { rate (Year 4) }\end{array}$ & $\begin{array}{l}\text { Rangeland } \\
\text { management: } \\
\text { Variable } \\
\text { stocking rate } \\
\text { (Year 4) }\end{array}$ \\
\hline $\begin{array}{l}\text { Calving } \\
\text { \% }\end{array}$ & 32 & 59 & 80 & 92 \\
\hline $\begin{array}{l}\text { Weaning } \\
\text { weight }\end{array}$ & $156 \mathrm{~kg}$ & $216 \mathrm{~kg}$ & $228 \mathrm{~kg}$ & $233 \mathrm{~kg}$ \\
\hline $\begin{array}{l}\text { Weaner } \\
\text { calf } \\
\text { income* }\end{array}$ & $\mathrm{R} 4680$ & $\mathrm{R} 6480$ & $\mathrm{R} 6840$ & $\mathrm{R} 6990$ \\
\hline $\begin{array}{l}\text { Income } \\
\text { per cow } \\
\text { mated }\end{array}$ & $\mathbf{R} 1498$ & $\mathbf{R 3 8 2 3}$ & $\mathbf{R 5 4 7 2}$ & $\mathbf{R 6 4 3 1}$ \\
\hline
\end{tabular}

* = Based on a weaner price of $\mathrm{R} 30 / \mathrm{kg}$

\section{CONCLUSION AND RECOMENDATIONS}

Findings of this study prove that with scientific based rangeland management practices, drastic improvement of beef production could be achieved. Since data were collected over a five year period with the same group of animals with the same genetic potential, it was clear that management did play a dominant role in the results. These findings also highlight the essential role of sustainable rangeland management for mitigating droughts. This is clearly illustrated by the weaning weights in the third year of the trail when the farm was subjected to a drought. These weights were still significantly higher when compared to results before the start of the trail when normal rainfall conditions were present, but no rangeland management practices were used.

These results indicate that the profitability of the communal and emerging sectors especially, could be drastically increased if efficient rangeland management practices are implemented in these sectors. Even in the commercial sector, it often happens that farmers obtain very good livestock production results and are even sometimes seen as top beef cattle farmers. These farmers are usually pleased with their rangeland management system. However, when their rangeland is evaluated, it is clear that the rangeland ecosystem is under severe pressure, as indicated by the appearance of pioneer plants such as Aristida species, or with less-palatable grasses such as Eragrostis plana, Cymbopogon pospischilii and Elionurus muticus, totally dominating the palatable grasses such as T. triandra, Digitaria eriantha and Anthephora pubescens. In this scenario, the lick intakes are also dramatically higher than what is good for 
the environment, while animal performance is entirely dependent on the lick programme, and the factory of the farm, which is rangeland, is being destroyed. Thus, supplementary feeding is used to mask the inefficiencies of the farmer's rangeland management. Unfortunately, these medium-term profitable practices are also used as examples for successful farming practices. It is therefore very important to distinguish between sustainable management practices and medium-term more profitable but unsustainable practices.

The long-term economic viability of extensive animal production systems depend mainly on rangeland, and sustainable animal production would only be possible when the rangeland and soil conditions are in a productive and stable state. Livestock producers should focus on sustainable rangeland management, including stocking rate rather than applying too many licks and nutritional supplements, as these would have a negative influence on rangeland condition, grazing capacity, and sustainability. The selection of adapted livestock which would be able to satisfy the bulk of their nutritional requirements from the available grazing would also minimise the need for supplementary feed and therefore limit long-term degradation.

Sustainable livestock production is, however, only possible with scientifically sound rangeland and livestock management over the long-term that ensures that rangeland conditions improve or are in an ecological optimum. As such, a management system that neither increases production cost nor negatively affects production as well as the environment should be developed to optimise animal productivity and hence, livestock profitability.

\section{IMPLICATIONS FOR AGRICULTURAL EXTENSION SERVICES}

Although the economical long-term value of efficient rangeland management is essential for optimal beef production, it is mainly underestimated by most farmers and even livestock scientists. Many developing small holding farmers as well as upcoming commercial farmers come from a communal livestock farming background, where rangeland management and beef production practices seldom exist. Including the fact that these farmers culturally still believe that livestock numbers is more important than individual performance, poor livestock performance (calving rate of $48 \%$ ) and natural resource degradation are most evident and contribute to poverty.

This group of farmers is also the focus point for departmental extension and development projects and initiatives such as the Comprehensive Agricultural Support Programme (CASP), livestock improvement schemes, and land care projects which focus to increase the productivity, profitability, and sustainability of these farmers. The focus point for these projects should be to recommend environmentally friendly grazing and livestock management practices that will increase grazing capacity, livestock production, and empower the farmers to become sustainable in producing good quality animals, thereby positively competing in the red meat industry in the long-term.

Agricultural extension advisers have a major role to play in conveying the outcome of this study to the whole spectrum of farming communities. This can be introduced through knowledge facilitation, workshops, study groups, farmer days, and demonstration trails. If adopted by individual farmers, it will contribute to long-term sustainability as well as mitigating the effect of droughts for all farmers in the livestock industry. 


\section{REFERENCES}

ACOCKS, J.P.H., 1988. Veldtypes of South Africa. Memoirs botanical survey South Africa. Pretoria: Government Printer.

FOUCHÉ, H.J., 1992. Simulering van die produksiepotensiaal van veld en die kwantifisering van droogte in die Sentrale Oranje-Vrystaat. PhD Thesis, University of the Orange Free State.

FREE STATE DEPARTMENT OF AGRICULTURE AND RURAL DEVELOPMENT (FSDARD), 2004. Management program for beef cattle. Bloemfontein, South Africa.

GROBLER, S.M., SCHOLTZ, M.M., GREYLING, J.P.C. \& NESER, F.W.C., 2014. Reproduction performance of beef cattle mated naturally following synchronization in the central bushveld bioregion of South Africa. S. Afr. J. Anim. Sci., 44(5):70-74.

HARDY, M.B. \& WALKER, R.S., 1991. Determining sample size for assessing species composition in grassland. J. Grassl. Soc. South. Afr., 8(2):70-73.

ISCW-DATABANK, 2018. Agriculture Research Council, Institute for Soil, Climate and Water. Pretoria, South Africa.

KOTZÉ, E., SANDHAGE-HOFMANN, A., MEINEL, J.A., DU PREEZ. C.C. \& AMELUNG, W., 2013. Rangeland management impacts on the properties of clayey soils along grazing gradients in the semi-arid grassland biome of South Africa. J. Arid Environ. 97:220-229.

MACVICAR, C.N., DE VILLIERS, J.M., LOXTON, R.F., VERSTER, E., LAMBRECHTS, J.J.N., MERRYWEATHER, F.R., LE ROUX, J., VAN ROOYEN, T.H. \& HARMSE, H.J., VON, M., 1977. Soil classification. A binomical system for South Africa. Pretoria: Department of Agricultural Technical Services.

MEISSNER, H.H., HOFMEYER, H.S., VAN RENSBURG, W.J.J. \& PIENAAR, J.P., 1983. Classification of livestock for realistic prediction of substitution values in terms of a biologically defined Large Stock Unit. Pretoria: Government Printer.

MEISSNER, H.H., SCHOLTZ, M.M. \& PALMER, A.R., 2013. Sustainability of the South African livestock sector towards 2050. Part 1: Worth and impact of the sector. S. Afr. J. Anim. Sci., 43(3):282-297.

SCHOLTZ, M.M. \& BESTER, J., 2010. Off-take and production statistics in the different South African cattle sectors. Results of structured survey. Appl. Anim. Husb. Rural Develop., 3(1):19-33.

VAN DER WESTHUIZEN, H.C., 2003. Die gebruik van degradasiegradiënte vir weiveldevaluering in ' $\mathrm{n}$ semi-ariede gebied. PhD Thesis, University of the Orange Free State.

VAN DER WESTHUIZEN, H.C., 2006. Weiveld evaluering vir optimale hulpbron benutting. Nguni J., 2006:13-33.

VAN DER WESTHUIZEN, H.C. \& SNYMAN, H.A., 2014. Evaluering van onderskeie veldbestuursbenaderings. In Gids tot die volhoubare produksie van weiding. $2^{\text {nd }}$ ed. (pp.146-147). Cape Town: Media 24.

VAN DER WESTHUIZEN, H.C., SNYMAN, H.A. \& FOUCHÉ, H.J., 2018. Sustainable veld management guidelines for the Free State. FSDARD, 1:27-59. 
S. Afr. J. Agric. Ext.

Vol. 48 No. 1, 2020: 112 - 121

http://dx.doi.org/10.17159/2413-3221/2020/v48n1a530
Van der Westhuizen, Mohlapo, De Klerk, Majola, Snyman, \& Neser

VAN DER WESTHUIZEN, H.C., SNYMAN, H.A., VAN RENSBURG, W.L.J. \& POTGIETER, J.H.J., 2001. The quantification of grazing capacity from grazing and production values for forage species in semi-arid grasslands of Southern Africa. Afr. J. Range For. Sci., 18(1):43-52.

VAN DER WESTHUIZEN, H.C., VAN RENSBURG, W.L.J. \& SNYMAN, H.A., 1999. The quantification of rangeland condition in a semi-arid grassland of Southern Africa. Afr. $J$. Range For. Sci., 16(2-3):49-61. 
